\title{
Kinetics and Quality of Quinoa Seeds After Drying and During Storage
}

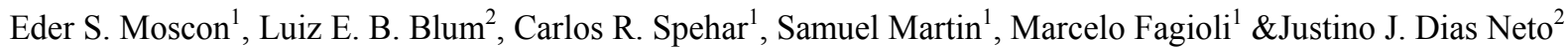 \\ ${ }^{1}$ Faculty of Agronomy and Veterinary Medicine, University of Brasília, Brasília, Brazil \\ ${ }^{2}$ Department of Plant Pathology, Institute of Biology, University of Brasília, Brasília, Brazil \\ Correspondence: Eder S. Moscon, Faculty of Agronomy and Veterinary Medicine, University of Brasília, Darcy \\ Ribeiro Campus, Asa Norte, s.n., 70.910-900, Brasília, Federal District, Brazil. Tel: 55-61-3107-7127. E-mail: \\ hederstolben@hotmail.com
}

Received: November 16, 2019

Accepted: December 16, 2019 Online Published: January 15, 2020

doi:10.5539/jas.v12n2p71

URL: https://doi.org/10.5539/jas.v12n2p71

\begin{abstract}
This study aimed to assess the effect of different drying forms, environments, and storage periods on germination and sanitary quality of quinoa seeds cv. BRS Syetetuba. Seeds were submitted to drying in forced air circulation chamber at 30,40 , and $50{ }^{\circ} \mathrm{C}$ and in a suspended tray, in full sun, until they reached $\pm 12 \%$ of moisture content. The observed drying data were adjusted to 10 mathematical models. The storage for 360 days was continuous in three different environments. Seeds were evaluated at 0,6 , and 12 months for germination, first count of germination, moisture content, and sanity tests. The experimental design was completely randomized, in a split split-plot scheme with four replicates. Among the studied models, Midilli was efficient in describing the drying curves of quinoa seeds. The storage environment influenced the loss of seed quality more than the drying temperature. The increased storage period caused a decrease on fungal seed incidence.
\end{abstract}

Keywords: Chenopodium quinoa Willd., environments, fungi, Midilli, temperature

\section{Introduction}

Quinoa seeds (Chenopodium quinoa Willd.) have striking nutritional qualities and have integrated the diet of Andean Peoples for hundreds of years (Bazile et al., 2016). Food and Agriculture Organization of the United Nations considered quinoa as one of the most promising cultures of humanity, not just for the beneficial properties to health, but also for the varieties of use (FAO, 2013). Quinoa adapts to different soil and climatic conditions, resist to abiotic factors and has a low production cost. In this form, this species may fit different agriculture systems (Restrepo et al., 2005). In Brazil, this culture was officially implemented to increase the variety of cultivation in production systems, besides contributing to food security and increasing producers' income (Spehar et al., 2011).

During the last years, this culture expanded greatly, mainly outside the origin country, causing an increase in the demand for its grains and derivatives, mainly in the USA, Canada, European Union, and Asia, which are the leading importers (Bazile et al., 2016). For these reasons, there is high potentiality for the growth of this cultivation at medium and large scale to satisfy the growing world demand for this product (Torres \& Salas, 2015).

A key factor for the success of this cultivation is the quality of seeds. Seeds quality must be kept high during storage, aiming at an optimal seedling establishment in the field, in order to guarantee the economic and productive benefits aimed by the producer (Tunes et al., 2014). Drying is a crucial stage of the productive cycle of seeds (Peske \& Villela, 2012), mainly employed to reduce the amount of water, delay the deterioration, and make them more suitable for storage (Oliveira et al., 2009). Storage, in turn, aims to preserve the initial quality of the seeds, protecting them from the weather, insects, and microorganisms (Ellis \& Hong, 2006).

Both the processes of drying ad storage are often neglected, even if they are critical stages of the productive cycle of seeds (Berbert et al., 2008). As refers to quinoa, as an example, most of the producers still use artisanal techniques, such as the natural drying on the plant, under the sun, or the shadow, and on the ground, and storage in environments with uncontrolled temperature and relative humidity (Quiroga et al., 2013). Moisture content, temperature, and storage time are critical factors in the preservation of the quality of the seed (Marcos-Filho, 2015). 
Even the same, the drying process may be detrimental to the quality of seeds, mainly due to its delay, or the use of high temperatures, excessive time of exposure to heated air, or the drying method employed (Menezes et al., 2012). Chemical, physical, and physiological alterations may occur during the process of water removal (Roveri José et al., 2004; Peske \& Villela, 2012). Considering the relevance of the drying process of the seeds, the theoretical study of the process and its practical application in the post-harvest stage is crucial, mainly dealing with cultures that have been produced for a short time, such as quinoa (Moscon et al., 2017).

Another crucial element to be considered is that the seed is one of the primary pathogen dissemination vehicles (Henning et al., 2011; Cardoso et al., 2015). Seeds contamination is often responsible for the introduction of new foci of infection of diseases in uncontaminated areas (Medeiros et al., 2015). Fungi play a crucial role as plant pathogens. Some infections caused by fungi appear as seeds are paced to germinate; other fungal infections appear during the storage, causing damages, mainly for production, and productivity (Henning et al., 2011).

As considering this context, there is still a lack of pieces of information on the drying process, and the effects of post-harvest stages, on the quality attributes of the seeds. In this form, the article aimed to analyze and to model the drying curve, and to assess the effects of different drying systems, environments, and storage times, on the germination, and sanitary quality of quinoa seeds.

\section{Material and Methods}

\subsection{Environment and Harvesting}

The study was conducted at the laboratory of 'Seed Studies' and 'Mycology' of the University of Brasilia (UnB), Brasilia, Federal District, Brazil. In the experiment, we used pure seeds of the cultivar BRS Syetetuba (Spehar et al., 2011), produced in the 'Água Limpa' experimental farm (FAL) of the UnB. Seed harvesting and threshing were hand made by the friction of the panicles. These processes were performed, 120 days after the emergence of the seedlings. Seed cleaning and size standardization were done by using a prototype of air machine and sieves.

\subsection{Drying and Storage}

Thin layer seed drying was performed in a stove with a forced ventilation system (Lucadema brand, model 82/150). The drying process was set as follows: D1—chamber at $30^{\circ} \mathrm{C}$; D2 - chamber at $40{ }^{\circ} \mathrm{C}$; D3 - chamber at $50{ }^{\circ} \mathrm{C}$; D4 - suspended terrace at one-meter height under the full sun. All treatments used three trays with the bottom constituted by netting $(50 \times 50 \mathrm{~cm})$. Each tray received $1.0 \mathrm{~kg}$ of seeds in a $\pm 1.5 \mathrm{~cm}$ thin layer. The trays were randomly set, and sed layers were hand revolved. The drying continued until the seeds reached the moisture content of $12 \pm 1.0 \%$.

The seed moisture content reduction during the drying was measured gravimetrically. The final determination was performed by the hoven method $\left(105^{\circ} \mathrm{C}\right)$ using three $5 \mathrm{~g}$ samples (Brasil, 2009a). The equilibrium moisture was determined by using three $5 \mathrm{~g}$ samples for each drying condition. After the drying process, the content of the trays was grouped, hand homogenized, and divided into $200 \pm 10 \mathrm{~g}$ portions. The repetitions were characterized and packaged in closed translucent $300 \mathrm{~mL}$ plastic bottles (Souza et al., 2016). The bottles were stored for 360 days as follows: $\mathrm{A} 1$ - cold chamber $\left(10^{\circ} \mathrm{C}\right.$ and $50 \% \mathrm{RH}$, initial); A2 - cold chamber $\left(19^{\circ} \mathrm{C}\right.$ and $40 \% \mathrm{RH}$, initial); A3-laboratory environment $\left(26^{\circ} \mathrm{C}\right.$ and $50 \% \mathrm{RH}$, initial). The temperature and the relative humidity of the air (RH) during storage (August 2017 to September 2018) were assessed (Digital datalogger Onset HOBO $^{\circledR}$ U12-011).

\subsection{Study the Kinetics of Drying}

To study the kinetics of drying, the assessment of the water removal rate from the seeds was performed according to equation 1 (Silva et al., 2018).

$$
\mathrm{WWR}=\left(\mathrm{Mw}_{0}-\mathrm{Mw}_{\mathrm{i}}\right) /\left[\mathrm{M}_{\mathrm{D}} \times\left(\mathrm{t}_{\mathrm{i}}-\mathrm{t}_{0}\right)\right]
$$

where, WRR: water removal rate $\left(\mathrm{kg} \mathrm{kg}^{-1} \mathrm{~h}^{-1}\right)$; $\mathrm{Mw}_{0}$ : previous total mass of water $\left(\mathrm{M}_{\mathrm{p}}\right.$ at $\left.\mathrm{t}_{0}-\mathrm{M}_{\mathrm{D}}\right), \mathrm{kg}$; $\mathrm{Mw}_{\mathrm{i}}$ : current total mass of water $\left(M_{p}\right.$ at $\left.t_{i}-M_{D}\right), k g ; M_{D}$ : dry matter $\left[M_{p} \times\left(1-U_{i}\right)\right], k g ; t_{0}$ : previous total drying time, $\mathrm{h}$; and $\mathrm{t}_{\mathrm{i}}$ : current total drying time, $\mathrm{h}$.

Moisture ratios (MR) were obtained for each temperature according to Equation 2.

$$
\mathrm{MR}=(\mathrm{M}-\mathrm{Me}) /(\mathrm{Mi}-\mathrm{Me})
$$

where, M: moisture content of the product at each drying time, decimal and drying bases (d.b); Mi: initial moisture content of the product, decimal (d.b.); and, Me: equilibrium moisture content of the product, decimal (d.b). 
Moisture content data determined during drying were submitted to mathematical models (Table 1) used to describe this phenomenon (Doymaz, 2014; Goneli et al., 2014; Santos et al., 2015; Mendonça et al., 2015; Maciel et al., 2017; Tao et al., 2018).

Table 1. Mathematical models used to predict the drying

\begin{tabular}{lll}
\hline Designation & Model & Equation \\
\hline Page & $\mathrm{MC}=\exp \left(-\mathrm{kt}^{\mathrm{n}}\right)$ \\
Henderson and Pabis & $\mathrm{MC}=\mathrm{a} \cdot \exp (-\mathrm{kt})$ \\
Midilli & $\mathrm{MC}=\mathrm{a} \cdot \exp \left(-\mathrm{kt}^{\mathrm{n}}\right)+\mathrm{b} \cdot \mathrm{t}$ \\
Wang e Singh & $\mathrm{MC}=1+\mathrm{a} \cdot \mathrm{t}+\mathrm{b} \cdot \mathrm{t}$ \\
Verma & $\mathrm{MC}=\mathrm{a} \cdot \exp (-\mathrm{kt})+(1-\mathrm{a}) \cdot \exp \left(-\mathrm{k}_{1} \mathrm{t}\right)$ \\
Thompson & $\mathrm{MC}=\exp \left\{\left[-\mathrm{a}-\left(\mathrm{a}^{2}+4 \mathrm{bt}\right)^{0.5}\right] / 2 \mathrm{~b}\right\}$ \\
Newton & $\mathrm{MC}=\exp (-\mathrm{kt})$ \\
Exponential Two Term & $\mathrm{MC}=\mathrm{a} \cdot \exp (-\mathrm{kt})+(1-\mathrm{a}) \cdot \exp (-\mathrm{kat})$ \\
Two Terms & $\mathrm{MC}=\mathrm{a} \cdot \exp \left(-\mathrm{k}_{0} \mathrm{t}\right)+\mathrm{b} \cdot \exp \left(-\mathrm{k}_{1} \mathrm{t}\right)$ \\
Page modified & $\mathrm{MC}=\exp (-\mathrm{kt})^{11}$
\end{tabular}

Note. MC: moisture content data dimensionless; $\mathrm{t}$ : drying time (min); $\mathrm{k}, \mathrm{k}_{0}, \mathrm{k}_{1}$ drying constants (s-1); $\mathrm{a}, \mathrm{b}, \mathrm{c}, \mathrm{n}$ : models' coefficients.

The adjust of the mathematical methods to the experimental data of drying was performed by non-linear regression analysis, by the Quasi-Newton method, by computational analysis. The degree of adjustment to each model was assessed considering the magnitude of the determination coefficient $\left(\mathrm{R}^{2}\right)$, the mean relative deviation (P), and the standard error of estimate (SE), the variance explained by the model (VE) (Goneli et al., 2014).

\subsection{Analysis of Physiological Quality}

Samples of the seeds were withdrawn at 0,6, and 12 months of storage to assess, by the following methods:

Moisture content (MC): Determined by the stove method at $105 \pm 3{ }^{\circ} \mathrm{C}$ for $24 \mathrm{~h}$ (Brasil, 2009a). The results were expressed as percentage wet bases (w.b).

Germination $(G)$ : Four subsamples of 50 seeds were seeded in transparent plastic boxes $(11 \mathrm{~cm} \times 11 \mathrm{~cm} \times 3 \mathrm{~cm})$ on two leaves of previously moistened Germitest paper. The boxes were stored in an incubation chamber (12 hours of light exposure; $25 \pm 2{ }^{\circ} \mathrm{C}$ ). The normal seedlings were counted on the $5^{\text {th }}$ day, and the results were expressed as a percentage (Brasil, 2009a; Souza et al., 2017).

First count of germination test $(F C)$ : Counting of the normal seedlings at two days after the beginning of the germination test and expressed as a percentage (Brasil, 2009a; Souza et al., 2017).

\subsection{Analysis of Sanitary Quality}

Seeds incubation was performed by the filter paper method, with freezing and 12 hours photoperiod (Brasil, 2009b). $2.0 \mathrm{~g}$ samples of seeds from each repetition were disinfected using a $2 \%$ solution of sodium hypochlorite for 2 minutes. Were extracted 200 seeds, divided into four groups of 50 units each, and seeded in plastic boxes, stored in incubation chambers at $20^{\circ} \mathrm{C}$ during 12 hours, frozen at $-20^{\circ} \mathrm{C}$ during 24 hours and later placed again in an incubation chamber at $25^{\circ} \mathrm{C}$ during seven days. After this, the seeds were examined individually using a magnifying glass with lighting and stereoscopic microscope. The percentage of infected seeds and the incidence of each genus were considered (Brasil, 2009b; Henning, 2015).

\subsection{Statistics}

For the analysis of physiological and sanitary quality, the completely randomized experimental design was used, in a split split plot scheme, with four repetitions. The factors were: the drying conditions, the place, and the storage period. Data were submitted to analysis of variance. The comparisons among the means were performed by the Tukey Test $(\mathrm{p} \leq 0.05)$. As refers to the storage time, the regression analysis was performed, and the models were adjusted based on the t-test $(\mathrm{p} \leq 0.05)$ and coefficient of determination $\left(\mathrm{R}^{2}\right)$. 


\section{Results and Discussion}

\subsection{Drying and Moisture Content}

After drying, the times spent, and the moisture content of the seeds were respectively for D1 to D4: 7, 5, 2.25, $1.5 \mathrm{~h}$ and $12.26 \%, 12.07 \%, 12.02 \%, 11.39 \%$ (Figure 1A). As observing the treatment submitted to drying in the stove, we observed that the rise of temperature caused a reduction of the drying time. Seeds placed in the suspended terrace required the shortest time and displayed the highest water removal rate. Figure 1B shows the opposite results in the seeds dried at $30^{\circ} \mathrm{C}$. It was also possible to observe that the water removal rate was higher at the beginning of the drying process, and later tended to be constant (Zonta et al., 2011).
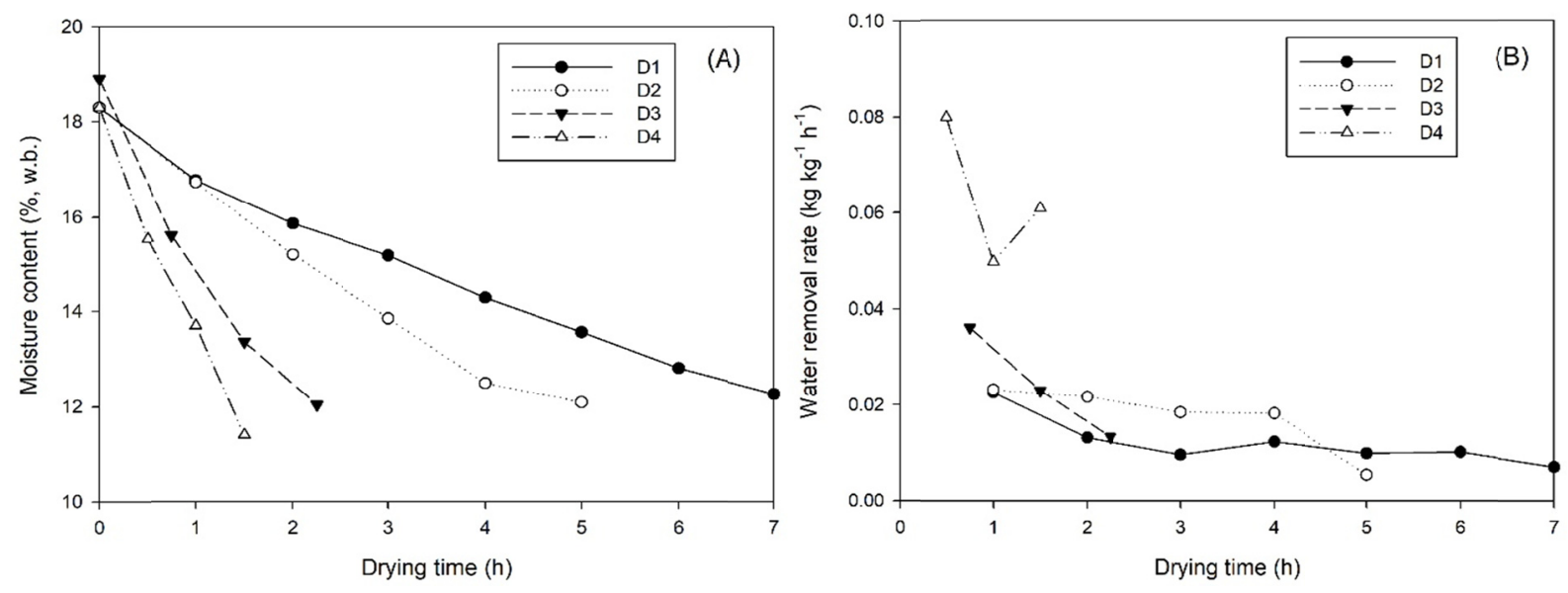

Figure 1. Moisture content (A) and water removal rate (B) during the drying of quinoa seeds under different treatments, according to the drying time

\subsection{Adjust of Mathematical Models}

During the process of water removal from the seeds, air renovation is crucial: the more the air is saturated with humidity, the more difficult is the removal of the water; the dryer the air, the faster the drying process (Carvalho \& Nakagawa, 2012). In the stove, the exchange between the internal and external air may be slower, mainly due to the physical impairment caused by the equipment, even the presence of a ventilation system. During the drying in the suspended terrace, although the psychrometric conditions of the air, such as relative humidity, or temperature has not been measured, the natural ventilation of the environment might have provided conditions for faster drying of the seeds, as compared with the stove drying.

As refers to the ten models analyzed, all of them were effective in describing the drying process of the quinoa seeds with a high coefficient of determination $\left(\mathrm{R}^{2}\right)$, and explained variance (VE), and low relative average error $(\mathrm{P})$, and standard deviation of the estimate (SE). Even the same, as considering the conditions in which the study was performed, we used the Midilli model, as it presented the highest number of favorable parameters to the studied drying forms (Table 2). 
Table 2. Coefficient of determination $\left(\mathrm{R}^{2}\right)$, relative average error (P, decimal), estimated standard deviation (SE, decimal), and explained variance (VE) of the ten analyzed models for the drying of quinoa seeds after different methods of drying

\begin{tabular}{|c|c|c|c|c|c|c|c|c|}
\hline \multirow{2}{*}{ Modelo } & \multicolumn{4}{|c|}{$30^{\circ} \mathrm{C}$} & \multicolumn{4}{|c|}{$40^{\circ} \mathrm{C}$} \\
\hline & $\mathrm{R}^{2}$ & $\mathrm{P}$ & $\mathrm{SE}$ & VE & $\mathrm{R}^{2}$ & $P$ & SE & VE \\
\hline Page & 0.999 & 0.018 & 2.71 & 0.994 & 0.999 & 0.011 & 1.92 & 0.997 \\
\hline Henderson-Pabis & 0.997 & 0.018 & 2.92 & 0.993 & 0.993 & 0.026 & 3.65 & 0,985 \\
\hline Midilli & 0.997 & 0.016 & 2.29 & 0995 & 0,999 & 0.011 & 1.81 & 0.997 \\
\hline Wang and Singh & 0.997 & 0.017 & 2.01 & 0.994 & 0.998 & 0.014 & 2.22 & 0.996 \\
\hline Verma & 0.998 & 0.013 & 1.53 & 0.99 & 0.997 & 0.015 & 2.44 & 0.994 \\
\hline Thopson & 0.997 & 0.018 & 2.92 & 0.993 & 0.993 & 0.026 & 3.65 & 0.985 \\
\hline Newton & 0.997 & 0.018 & 2.92 . & 0.993 & 0.993 & 0.026 & 3.65 & 0.985 \\
\hline Exp. Dois Termos & 0.997 & 0.018 & 2.92 & 0.993 & 0.993 & 0.026 & 3.65 & 0.985 \\
\hline Dois termos & 0.997 & 0.018 & 2.96 & 0.993 & 0,994 & 0.023 & 3.35 & 0.989 \\
\hline Page Modified & 0.997 & 0.018 & 2.92 & 0.994 & 0.993 & 0.026 & 3.65 & 0.985 \\
\hline \multirow{2}{*}{ Model } & \multicolumn{4}{|c|}{$50^{\circ} \mathrm{C}$} & \multicolumn{4}{|c|}{ AMB } \\
\hline & $\mathrm{R}^{2}$ & $\mathrm{P}$ & $\mathrm{SE}$ & VE & $\mathrm{R}^{2}$ & $\mathrm{P}$ & $\mathrm{SE}$ & VE \\
\hline Page & 0.999 & 0.002 & 0.27 & 0.999 & 0.994 & 0.022 & 3.65 & 0.987 \\
\hline Henderson-Pabis & 0.997 & 0.014 & 1.53 & 0.995 & 0.985 & 0.034 & 6.69 & 0.969 \\
\hline Midilli & 0.999 & 0.000 & 0.000 & 1.000 & 0.999 & 0.008 & 1.13 & 0.999 \\
\hline Wang and Singh & 0.999 & 0.004 & 0.43 & 0.999 & 0.998 & 0.012 & 1.46 & 0,996 \\
\hline Verma & 0.999 & 0.006 & 0.64 & 0.999 & 0.999 & 0.001 & 0.00 & 0.998 \\
\hline Thopson & 0.997 & 0.014 & 1.53 & 0.994 & 0.985 & 0.034 & 6.69 & 0.969 \\
\hline Newton & 0.997 & 0.014 & 1.53 & 0.994 & 0.985 & 0.034 & 6.69 & 0.969 \\
\hline Exp. Dois Termos & 0.999 & 0.002 & 0.29 & 0.999 & 0.993 & 0.023 & 4.11 & 0.985 \\
\hline Dois termos & 0.998 & 0.013 & 1.50 & 0.995 & 0.985 & 0.033 & 6.63 & 0.971 \\
\hline Page Modified & 0.997 & 0.014 & 1.53 & 0.994 & 0.985 & 0.034 & 6.69 & 0.970 \\
\hline
\end{tabular}

The Midili model was satisfactory. It described the relationship between the estimated and observed data with high concordance in each analyzed drying condition (Figure 2). The same method was used to describe the kinetics of drying of different seeds, such as watermelon (Doymaz, 2014), Carapa guayensis (Mendonça et al., 2015) and pea (Tao et al., 2018).
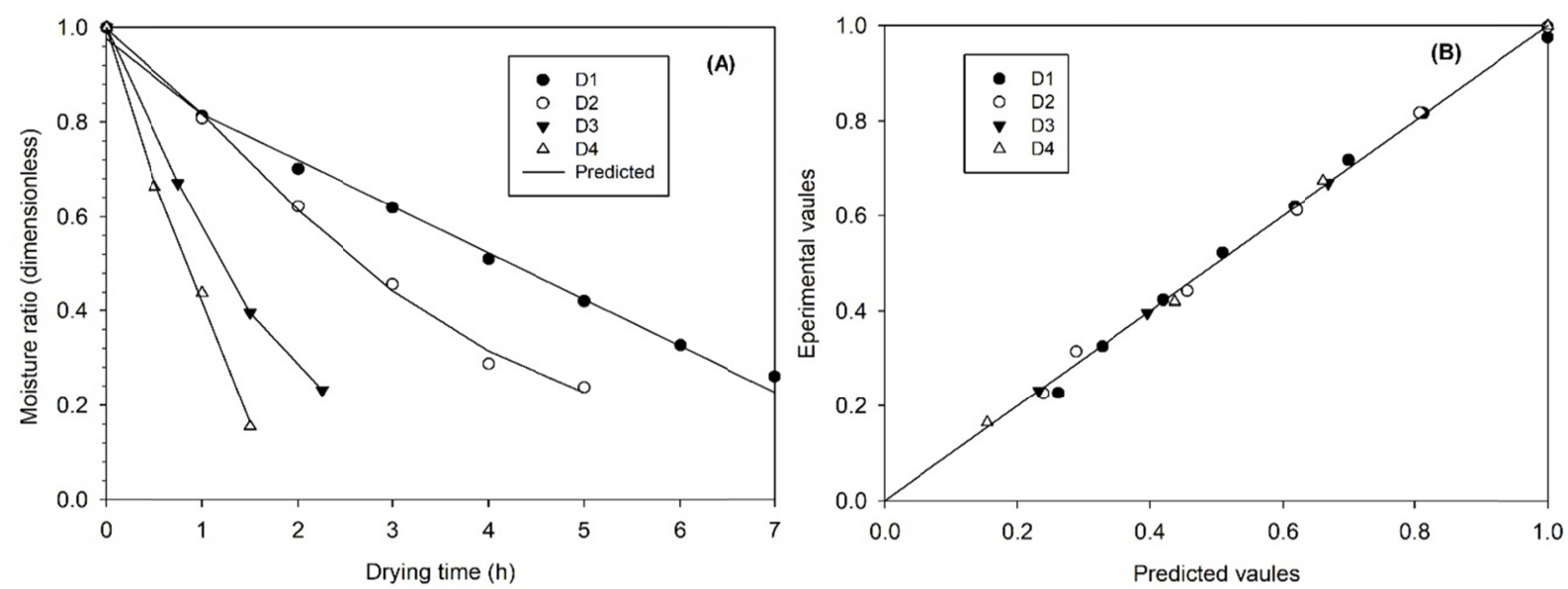

Figure 2. Moisture ratio (A) and distribution of the residuals (B) of the values observed and adjusted according to the Midilli model for quinoa seeds submitted to different forms of drying

\subsection{Quality Seeds After Drying and Storage}

During the storage, the climatic variables showed distinct behaviors in different environments. As refers to A1, A2 and A3, the average temperatures were: $11.4 \pm 0.2{ }^{\circ} \mathrm{C}, 19.1 \pm 0.4{ }^{\circ} \mathrm{C}$ and $26.5 \pm 7.3{ }^{\circ} \mathrm{C}$ and the air relative humidity: $53.7 \pm 1.5 \%, 40.1 \pm 6.5 \%$, and $50.9 \pm 19.5 \%$, respectively. A3 treatment displayed the higher amplitudes 
of heat and relative humidity of the air. The values varied between $21.4{ }^{\circ} \mathrm{C}$ to $31.1{ }^{\circ} \mathrm{C}$ temperature, and 19.4 to $77.3 \%$ relative humidity.

As refers to the moisture content of the seeds during storage, the analysis of variance pointed out a significant interaction only between the drying method, and the periods. The treatments submitted to drying at $30{ }^{\circ} \mathrm{C}$ and under the sunlight presented the highest values of moisture content at the beginning and the end of the assessed period, and a decrease at the end. The remaining treatments displayed a continuous increase in moisture content during the storage period. Treatment D1 displayed the highest moisture content at six months of storage (12.75\%). Treatment D3 displayed the lowest moisture content (11.37\%) at the beginning of storage (Figure 3).

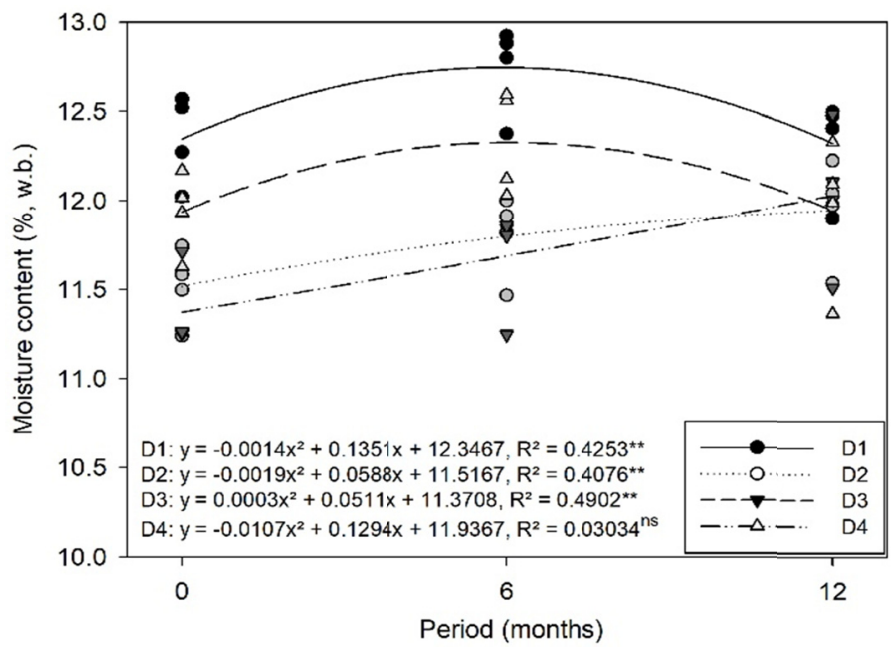

Figure 3. Moisture content ( $\%$, wet basis) of quinoa seeds submitted to different drying methods, according to the storage time

The variations of the moisture content during the storage were probably mainly due to loss of hermeticity of the package and to their opening at the sampling. Due to their hygroscopicity, the moisture content of seeds tends to vary according to the temperature and relative humidity of the storage environment (Peske \& Villela, 2012). It is essential to point out that the moisture content of seeds should not exceed $12-14 \%$ in order to preserve them safely (Carvalho \& Nakagawa, 2012). As the moisture content is preserved lower than this, the respiratory processes are low, promoting the quality of the seeds (Zucareli et al., 2015).

In the germination of seeds was observed significant interaction of the factors to which the seeds were submitted (Table 3). Drying treatments did not cause significant differences among samples stored in A1 or A2 conditions. In both cases, germination continued high, over 90\%. Even the same A3 storage caused a significant effect between D1, D4, and the remaining treatments. In this environment, germination decrease more significantly in D1 and D4, but stayed high in D2, and D3 (69\%, 83\%, 92\% e 93\%, respectively).

Table 3. Germination (\%) of quinoa seeds submitted to different drying methods and storage environments

\begin{tabular}{llll}
\hline \multirow{2}{*}{ Drying methods } & \multicolumn{3}{c}{ Storage environment } \\
\cline { 2 - 3 } & A1 & A2 & A3 \\
\hline & $----10---10$ & $64 \mathrm{cB}$ \\
D1 & $95 \mathrm{aA}$ & $94 \mathrm{aA}$ & $92 \mathrm{aB}$ \\
D3 & $94 \mathrm{aAB}$ & $95 \mathrm{aA}$ & $93 \mathrm{aB}$ \\
D4 & $95 \mathrm{aA}$ & $95 \mathrm{aA}$ & $82 \mathrm{bB}$
\end{tabular}

Note. Averages followed by the same lowercase letters in the row and upper-case letter in the line do not differ significantly among each other by the Tukey test at $5 \%$ probability. Drying conditions: D1—chamber at $30{ }^{\circ} \mathrm{C}$; D2 - chamber at $40{ }^{\circ} \mathrm{C}$; D3 - chamber at $50{ }^{\circ} \mathrm{C}$; D4- suspended terrace at one-meter height under the full sun. Storage conditions: A1 - cold chamber $\left( \pm 10{ }^{\circ} \mathrm{C}\right)$; A2 - cold chamber $\left( \pm 19^{\circ} \mathrm{C}\right)$; A3-laboratory environment $\left(26 \pm 2{ }^{\circ} \mathrm{C}, 50 \pm 10 \% \mathrm{RH}\right)$. 
The association between the laboratory environment and some of the drying methods contributed to the decrease of germination observed in the experiment. Probably the delay or the excessive speed of water removal from the seeds during drying caused the extreme values observed. These latent damages can only be perceived after the storage, causing a decrease in germination and vigor (Labbé, 2012). The increase in drying speed may cause an increase in the incidence of cracks, both in the integuments and in the cotyledons and embryonic axis (Peske \& Villela, 2012).

During the 12 months storage in both A1, and A2 environments, the seeds preserved over $90 \%$ germination, independently from the drying conditions. Seeds preserved in the A3 environment preserved high germination only as dried at $40{ }^{\circ} \mathrm{C}$ and $50{ }^{\circ} \mathrm{C}$ (D2 and D3, respectively). Seeds preserved in the natural environment (D4) and in the stove at $30{ }^{\circ} \mathrm{C}$ (D1) displayed a reduction of germination, reaching respectively $64 \%$, and $25 \%$, after the 12 months storage (Figure 4).
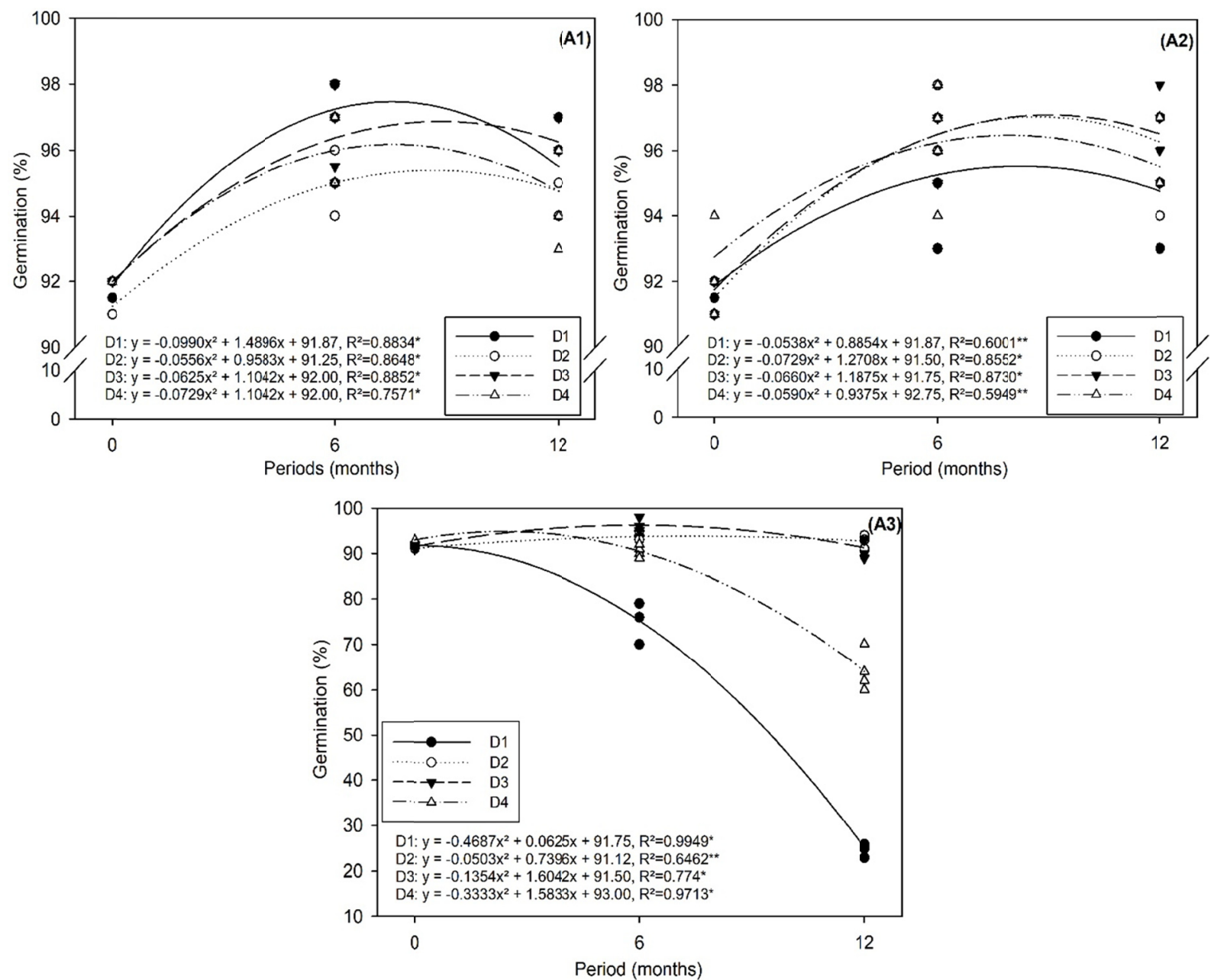

Figure 4. Germination (\%) of quinoa seeds submitted to different drying methods and storage environments, to the storage time

Several authors have already described the influence of the storage environment on the germination of seeds. Dias et al. (2016) claim, seeds of Jatropha curcas loose germination capacity as preserved in laboratory conditions $\left(23 \pm 3^{\circ} \mathrm{C}\right.$ and $\left.64 \pm 11 \% \mathrm{RH}\right)$, but preserve it as stored in cold chamber $\left(10 \pm 2{ }^{\circ} \mathrm{C}\right.$ and $\left.55 \pm 5 \% \mathrm{RH}\right)$. According to the authors, the storage in the cold chamber is the best form to store the seeds for 12 months.

The storage of seeds of Adzuki beans (Vigna angularis) at $25.4 \pm 3{ }^{\circ} \mathrm{C}$ and $67.3 \pm 3 \% \mathrm{RH}$ cause a reduction in quality, germination, size, and dry mass of the seedlings (Tavares et al., 2015). The physiological quality of beans seeds (Phaseolus vulgaris) decreased after 18 months of storage under uncontrolled condition of 
temperature and humidity (Zucareli et al., 2015). The drying at $42{ }^{\circ} \mathrm{C}$ and the storage for eight months reduced the physiological quality of pepper seeds (Silva et al., 2018).

Storage time increase also reduced the quality of seeds of Hymenaea stigonocarpa (Coradi et al., 2016). Zonta et al. (2011) described the same decrease in the germination of the seeds of Jatropha curcas L. during 270 days of storage after drying in stove at $33{ }^{\circ} \mathrm{C}$ and under the sun. The decrease in germination was associated with the latent damages caused by the slow drying process.

Even the same, it is crucial to assess both abiotic (moisture content and temperature) and biotic factors (fungi and pests) during the storage of the seeds. Both classes of factors may intensify the degradation process, acting individually or in combination, and causing, in this form, irreversible losses in the product's quality (Giorni et al., 2008; Coradi et al., 2016).

\subsection{Storage Fungi and Quality}

In this work, there was no statistically significant interaction between the factors (drying conditions and the place storage) for the percentage of infected seeds (IS), but there was for the storage periods. Figure 5 highlights the significant differences between the different fungi contaminations observed.
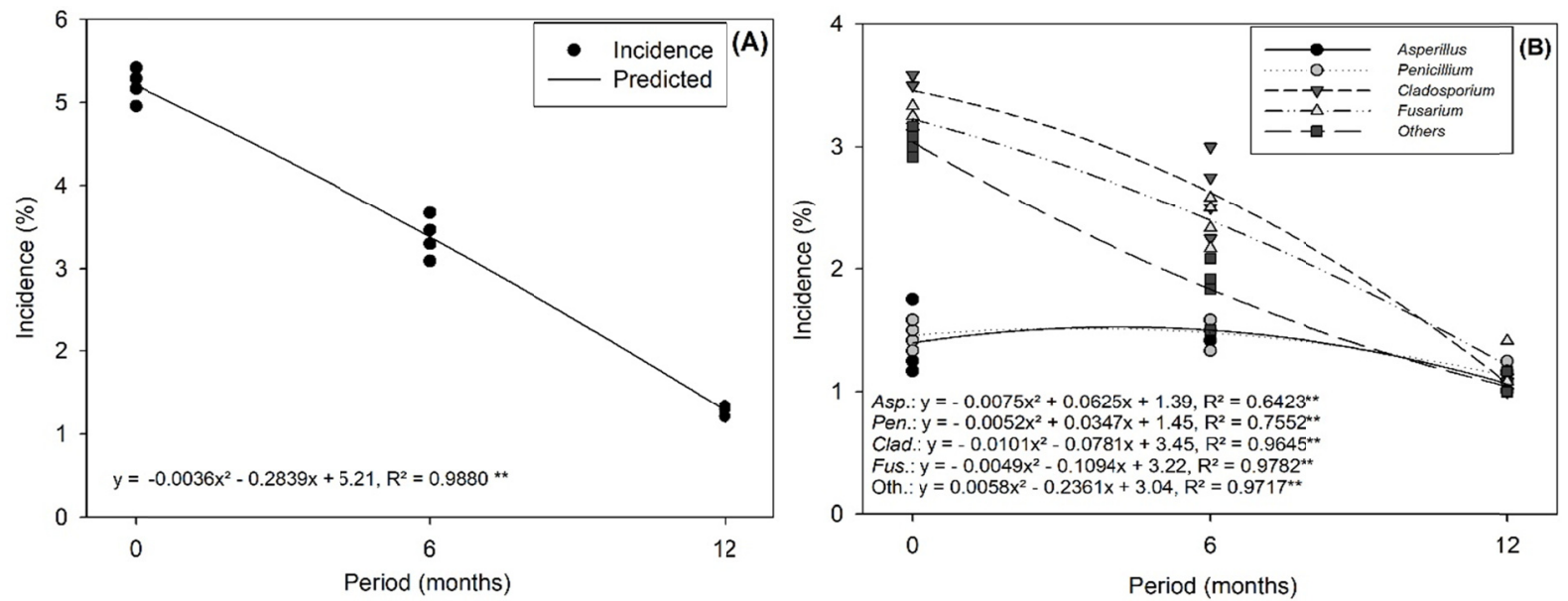

Figure 5. Incidence of contaminated seeds (A), and fungi (B) in quinoa seeds submitted to different methods of drying and storage, at three assessing periods $(0,6$, and 12 months)

The variations among the drying methods and storage environments did not influence significantly the quality of seeds infected by fungi. However, the data showed significant effect of the storage period on the incidence of fungi. Contamination by fungi displayed the highest value the beginning of the storage period, decreased along the storage, reaching null in some treatments, at the end of the experimental period. The decrease of contaminated seeds may be explained by the loss of viability of fungal spores and dormant mycelia during the storage. As no abrupt increase in the moisture content of the seeds was observed, the multiplication of fungi was hindered, decreasing, in this form the contamination. The storage at low moisture content (14\%) in hermetic or not hermetic conditions preserved the original quality of corn seeds, with low growth of fungi, even after months of storage (Suleiman et al., 2018). Decreases in oat seed contamination have also been observed during storage (Rupollo et al., 2006).

The most common genera of fungi found in this experiment were Aspergillus spp., Penicillium spp., Fusarium spp., and Cladosporium spp. At the beginning of the experiment, we observed the highest incidence of Cladosporium spp. (4.92\%), followed by Fusarium spp. (4.46\%). Also, at the second assessing time the genera Cladosporium spp. (3.25\%), and Fusarium spp. (2.79\%) prevailed. At the last assessing time we observed the highest incidence of Fusarium spp. (0.42\%), Penicillium spp. (0.25\%), and Aspergillus spp. (0.13 \%) (Figure 5). Our experiment detected other genera of fungi, but the lack of sporulation prevented their identification. Some genera occurred with very low frequency, or just once, being, therefore, just quoted, as in the case of Alternaria spp., Curvularia spp. Phoma spp., and Phomopsis spp. 
Guimaraes and Carvalho (2014) associated the presence of Cladosporium spp. in bean seeds, with their storage, affecting their quality. Silva and Lourenço Jr. (2009) described similar pathogens in seeds of five other Brazilian quinoa strains. Antonello et al. (2009) described the presence of the fungi Aspergillus spp., and Penicillium spp. during the storage of corn seeds in plastic packages. Additionally, fungi of the genus Fusarium found in seeds of quinoa have already been described as causing agents of damping-off (Drímalková \& Veverka, 2004).

It is crucial to point out that, due to their low incidence, in this experiment fungi did not influence the germination of the seeds directly, mainly at the end of the storage period. Even the same, it is essential to pay attention to the handling of the seeds to avoid or reduce the contamination, mainly due to their pathogenic potential. Fungi may deteriorate the seeds or kill them before, or after the planting.

\section{Conclusions}

The Midilli model was efficient to describe the drying curves of quinoa seeds. Regardless of the drying temperature, the storage environment influenced the loss of seed germination quality. There was a reduction in the incidence of fungi with increasing storage time.

\section{Acknowledgements}

This study was financed in part by the Coordenação de Aperfeiçoamento de Pessoal de Nível Superior-Brasil (CAPES)-Finance Code 001, with scientific and structural support from the University of Brasilia (UnB).

\section{References}

Antonello, L. M., Muniz, M. B., Brand, S. C., Vidal, M. D., Garcia, D., Ribeiro, L., \& Santos, V. (2009). Qualidade de sementes de milho armazenadas em diferentes embalagens. Ciência Rural, 39(7), 2191-2194.

Bazile, D., Jacobsen, S.-E., \& Verniau, A. (2016). The global expansion of quinoa: Trends and limits. Frontiers in Plant Science, 7, 622-630. https://doi.org/10.3389/fpls.2016.00622

Berbert, P. A., Carlesso, V. O., Silva, R. F., Araújo, E. F., Thiébaut, J. T. L., \& Oliveira, M. T. R. (2008). Qualidade fisiológica de semente de mamão em função da secagem e do armazenamento. Revista Brasileira de Sementes, 30(1), 40-48. https://doi.org/10.1590/S0101-31222008000100006

Brasil, Ministério da Agricultura Pecuária e Abastecimento. (2009a). Regras para análises de sementes (p. 395). Secretaria de Defesa Agropecuária. Brasília, SNAD/DNDV/CLAV.

Brasil, Ministério da Agricultura, Pecuária e Abastecimento. (2009b). Manual de Análise Sanitária de Sementes (p. 200). Secretaria de Defesa Agropecuária. Brasília, SNAD/DNDV/CLAV.

Cardoso, A. M. S., David, A. M. S. S., Carvalho, A. R. J., Sales, R. P., Oliveira, P. C. C., \& Souza, M. D. C. (2015). Tratamento químico na qualidade sanitária e na germinação de sementes de Jatropha curcas L. (Euphorbiaceae). Comumnicata Scientiae, 6(1), 41-48. https://doi.org/10.14295/cs.v6i1.538

Carvalho, N. M., \& Nakagawa, J. (2012). Sementes: Ciência, tecnologia e produção. Campinas, SP: Funep.

Coradi, P. C., Pereira, T. L. L., \& Camilo, L. J. (2016). Quality of seeds of jatobá-do-cerrado processed and stored in diferents forms. Semina: Ciências Agrárias, 37(2), 665-684. https://doi.org/10.5433/1679-0359. 2016v37n2p665

Dias, D. C. F. S., Oliveira, G. L., Vallory, G. G., Silva, L. J., \& Soares, M. M. (2016). Physiological changes in Jatrophacurcas L. seeds during storage. Journal of Seed Science, 38(1), 041-049. https://doi.org/10.1590/ 2317-1545v38n1155449

Doymaz, I. (2014). Experimental study and mathematical modeling of thin-layer infrared drying of watermelon seeds. Journal of Food Processing and Preservation, 38, 1377-1384. https://doi.org/10.1111/jfpp.12217

Drímalková, M., \& Veverka, K. (2004). Seedlings damping-off of Chenopodium quinoa Willd. Plant Protection Science, 40(1), 5-10. https://doi.org/10.17221/3119-pps

Ellis, R. H., \& Hong, T. D. (2006). Temperature sensitivity of the low-moisture-content limit to negative seed longevity-moisture content relationships in hermetic storage. Annals of Botany, 97, 785-791. https://doi.org/ $10.1093 / \mathrm{aob} / \mathrm{mcl} 035$

FAO. (2013). La ONU declara al 2013 año internacional de la quinua. Retrieved from http://www.fao.org/ in-action/agronoticias/detail/es/c/508947

Giorni, P., Battilani, P., Pietri, A., \& Magan, N. (2008). Effect of aw and $\mathrm{CO}_{2}$ level on Aspergillus flavus growth and aflatoxin production in high moisture maize post-harvest. International Journal of Food Microbiology, 122(1-2), 109-113. https://doi.org/10.1016/j.ijfoodmicro.2007.11.051 
Goneli, A. L. D., Vieira, M. C., Vilhasanti, H. C. B., \& Gonçalves, A. A. (2014). Modelagem matemática e difusividade efetiva de folhas de aroeira durante a secagem. Pesquisa Agropecuária Tropial, 44(1), 56-64. https://doi.org/10.1590/S1983-40632014000100005

Guimaraes, G. R., \& Carvalho, D. D. C. (2014). Incidência e caracterização morfológica de Cladosporium herbarum em feijão comum cv. 'Pérola'. Revista Brasileira de Biociência, 12(3), 137-140. Retrieved from http://www.ufrgs.br/seerbio/ojs/index.php/rbb/article/view/2823

Henning, A. A. (2015). Guia prático para identificação de fungos mais frequentes em sementes de soja. Brasília, DF: Embrapa.

Henning, F. A., Jacob Junior, E. A., Mertz, L. M., \& Peske, S. T. (2011). Qualidade sanitária de sementes de milho em diferentes estádios de maturação. Revista Brasileira de Sementes, 33(2), 316-321.

Labbé, L. M. B. (2012). Armazenamento de sementes. In S. T. Peske, F. A. Villela, \& G. E. Meneghello (Eds.), Sementes: Fundamentos científicos e tecnológicos. Pelotas, RS: UFPel.

Maciel, R. M. G., Afonso, M. R. A., Costa, J. M. C., Severo, L. S., \& Lima, N. D. (2017). Mathematical modeling of the foam-mat drying curves of guava pulp. Revista Brasileira de Engenharia Agrícola $e$ Ambiental, 21(10), 721-725. https://doi.org/10.1590/1807-1929/agriambi.v21n10p721-725

Marcos-Filho, J. (2015). Fisiologia de sementes de plantas cultivadas. Londrina, PR: Abrates.

Medeiros, J. G. F., Araújo Neto, A. C., Silva, E. C., Huang, M. N., \& Nascimento, L. C. (2015). Qualidade sanitária de sementes de Caesalpinia ferrea: Incidência de fungos, controle e efeitos na qualidade fisiológica com o uso de extratos vegetais. Floresta, 45(1), 163-174. https://doi.org/10.5380/rf.v45i1.34074

Mendonça, A. P., Sampaio, P. T. B., Almeida, F. A. C., Ferreira, R. F., \& Novais, J. M. (2015). Determinação das curvas de secagem das sementes de andiroba em secador solar. Revista Brasileira de Engenharia Agrícola e Ambiental, 19(4), 382-387. https://doi.org/10.1590/1807-1929/agriambi.v19n4p382-387

Menezes, N. L., Pasqualli, L. L., Barbieri, A. P. P., Vidal, M. D., \& Conceição, G. M. (2012). Temperaturas de secagem na integridade física, qualidade fisiológica e composição química de sementes de arroz. Pesquisa Agropecuária Tropical, 42(4), 430-436. https://doi.org/10.1590/S1983-40632012000400011

Moscon, E. S., Martin, S., Spehar, C. R., Devilla, I. A., \& Rodolfo Junior, F. (2017). Cinética de secagem de grãos de quinoa (Chenopodium quinoa Willd.). Revista Engenharia na Agricultura, 25(4), 318-328. https://doi.org/10.13083/reveng.v25i4.773

Oliveira, M. T. R., Berbert, P. A., Vieira, H. D., Thiébaut, J. T. L., Carlesso, V. O., \& Pereira, R. C. (2009). Avaliação do vigor de sementes de carambola em função da secagem e do armazenamento. Revista Brasileira de Engenharia Agrícola e Ambiental, 13(4), 477-482. https://doi.org/10.1590/S1415-43662009 000400016

Peske, S. T., \& Villela, F. A. (2012). Secagem de sementes. In S. T. Peske, F. A. Villela, \& G. E. Meneghello (Eds.), Sementes: Fundamentos científicos e tecnológicos. Pelotas, RS: UFPel.

Quiroga, C., Escalera, R., Aroni, G., Bonifacio, A., González, J. A., Villca, M., ... Ruiz, A. (2013). Procesost radicionales e innovaciones tecnológicas en la cosecha, beneficiado e industrialización de la quinua. In Bazile et al. (Eds.), Estado del arte de laquinua en el mundo en 2013. Montpellier, Francia: FAO \& CIRAD.

Restrepo, L. A. M., Vianchá, L. M., \& Ballesteros, J. P. (2005). Analisis de variables estratégicas para la conformación de una cadena productiva de quinua en Colombia. Innovar, 15(25), 103-119.

Roveri José, S. C. B., Von Pinho, E. V. R., Von Pinho, R. G., \& Silveira, C. M. (2004). Padrões eletroforéticos da enzima $\alpha$-amilase em sementes de milho submetidas a alta temperatura de secagem. Revista Brasileira de Sementes, 26(1), 77-83. https://doi.org/10.1590/S0101-31222004000100012

Rupollo, G., Gutkoski, L. C., Martins, I. R., \& Elias, M. C. (2006). Efeito da umidade e do período de armazenamento hermético na contaminação natural por fungos e a produção de micotoxinas em grãos de aveia. Ciência e Agrotecnologia, 30(1), 118-125. https://doi.org/10.1590/S1413-70542006000100017

Santos, D. C., Queiroz, A. J. M., Figueirêdo, R. M. F., \& Oliveira, E. N. A. (2015). Sun drying of residual annatto seed powder. Acta Scientiarum, 37(1), 161-166. https://doi.org/10.4025/actascitechnol.v37i1.20582

Silva, A. P., \& Lourenço Junior, V. (2009). Ocorrência de fungos em sementes de cinco linhagens brasileiras de quinoa (ocorrência de fungos em sementes de quinoa). Campo Digital, 4(1), 137-141. 
Silva, H. W., Vale, L. S. R., Silva, C. F., Souza, R. C., \& Soares, R. S. (2018). Drying kinetics and physiological quality of 'Cabacinha' pepper seeds during storage. Revista Brasileira de Engenharia Agrícola e Ambiental, 22(4), 292-297. https://doi.org/10.1590/1807-1929/agriambi.v22n4p292-297

Souza, F. F. J., Devilla, I. A., Souza, R. T. G., Teixeira, I. R., \& Spehar, C. R. (2016). Physiological quality of quinoa seeds submitted to different storage conditions. African Journal of Agricultural Research, 11(15), 1299-1308. https://doi.org/10.5897/ajar2016-10870

Souza, F. F. J., Souza, J. E. A., Souza, N. O. S., Spehar, C. R., \& Jesus, T. F. (2017). Standardizing germination tests for quinoa seeds. African Journal of Agricultural Research, 12(3), 155-160. https://doi.org/10.5897/ AJAR2016.11820

Spehar, C. R., Rocha, J. E. S., \& Santos, R. L. B. (2011). Desempenho agronômico e recomendações para cultivo de quinoa (BRS Syetetuba) no cerrado. Pesquisa Agropecuária Tropical, 41(1), 145-147. https://doi.org/ 10.5216/pat.v41i1.9395.

Suleiman, R., Bern, C. J., Brumm, T. J., \& Rosentrater, K. A. (2018). Impact of moisture content and maize weevils on maize quality during hermetic and non-hermetic storage. Journal of Stored Products Research, 78, 1-10. https://doi.org/10.1016/j.jspr.2018.05.007

Tao, Z., Yang, Z., Yu, F., \& Yang, Z. (2018). Effect of ultrasound on heat pump drying characteristics of pea seeds. International Journal of Food Engineering, 14(11-12), 1-14. https://doi.org/10.1515/ijfe-2018-0204

Tavares, C. J., Araújo, A. C. F., Jakelaitis, A., Resende, O., Sales, J. F., \& Freitas, M. A. M. (2015). Qualidade de sementes de feijão-azuki dessecadas com saflufenacil e submetidas ao armazenamento. Revista Brasileira de Engenharia Agrícola e Ambiental, 19(12), 1197-1202. https://doi.org/10.1590/1807-1929/agriambi. v19n12p1197-1202

Torres, L. A. C., \& Salas, J. C. D. (2015). Posibilidades en el comercio internacional de la quinua: un análisis desde la perspectiva de la competitividad. Equidad \& Desarrollo, 24, 119-137.

Tunes, L. V. M., Fonseca, D. Â. R., Meneghello, G. E., Reis, B. B., Brasil, V. D., Rufino, C. A., \& Vilella, F. A. (2014). Qualidade fisiológica, sanitária e enzimática de sementes de arroz irrigado recobertas com silício. Revista Ceres, 61(5), 675-685. https://doi.org/10.1590/0034-737X201461050011

Zonta, J. B., Araujo, E. F., Araujo, R. F., \& Dias, L. A. S. (2011). Diferentes tipos de secagem: Efeitos na qualidade fisiológica de sementes de pinhão-manso. Revista Brasileira de Sementes, 33(4), 724-734. https://doi.org/10.1590/S0101-31222011000400014

Zucareli, C., Brzezinski, C. R., Abati, J., Werner, F., Ramos Júnior, E. U., \& Nakagawa, J. (2015). Qualidade fisiológica de sementes de feijão carioca armazenadas em diferentes ambientes. Revista Brasileira de Engenharia Agrícola e Ambiental, 19(8), 803-809. https://doi.org/10.1590/1807-1929/agriambi.v19n8 p803-809

\section{Copyrights}

Copyright for this article is retained by the author(s), with first publication rights granted to the journal.

This is an open-access article distributed under the terms and conditions of the Creative Commons Attribution license (http://creativecommons.org/licenses/by/4.0/). 